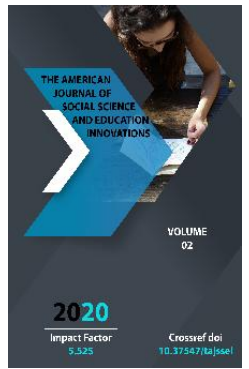

Journal Website: http://usajournalshub.c om/index,php/tajssei

Copyright: Original content from this work may be used under the terms of the creative commons attributes 4.0 licence.

\section{Internal Migration Processes And Population Crafts In The Emirate Of Bukhara}

Khalikov Zokir Eshboltayevich

A candidate of historical sciences of Termez State University, Uzbekistan

Sharifiy Gavharshodbegim

Scientific researcher of Termez State University, Uzbekistan, Uzbekistan

\title{
ABSTRACT
}

This article analyzes the scientific data on the role of migrants in the central cities of the Bukhara Emirate in the late XIX and early XX centuries in their crafts and production.

\section{KEYWORDS}

Emirate of Bukhara, Karakol, Nurata, Karshi, Guzar, Yakkabag, Chorjoi, Boysun, Denau, Mangit, Sughd

\section{INTRODUCTION}

The territory of the Emirate of Bukhara was 225,000 square kilometers, equal to the territory of present-day Italy. The emirate had 28 principalities, including Karakol, Nurata, Karshi, Guzar, Yakkabag, Chorjoi, Boysun, Denau, Sherabad, Gissar, Kulob, Qabodiyon and others. The principalities had the same territory as the provinces. In this regard, Vobkent and Gijduvan districts close to Bukhara are mentioned. Bukhara, Uzbek, Kazakh, Kyrgyz, Turkmen, Tajik, Jewish, Arab and Afghan nationalities live in Bukhara. (Sayyid Amir Alimkhan, 1991)
According to Amir Alimkhan, the Bukhara emirs believed that the Mangits were of Uzbek descent and, according to Mongol tradition, they were carried on white felt by sayyids, khojas and mullahs. It is said that the Mongols were not Mongols, but one of the ancient Turkic peoples. (Ibid., p. 3). Bukhara is one of the oldest cities in Central Asia, ruled by various kings. For example, the play admits that "the Mangits ruled from 1783 to 1920." European scholars are skeptical of the large population of medieval Central Asian cities. For example, during the Navoi period, the 
population of Samarkand was several thousand people. In the 12th century, Masson acknowledged that the population of Herat was between half a million and one million (Masson, 1948).

\section{MATERIALS AND METHODS}

The population of Bukhara spoke Uzbek and Tajik languages. The Uzbek language was spoken in markets, shops, on the streets, at home, while in Tajik it was spoken by educated and courtiers. This indicates that even before the Tajik-speaking population, there was an assimilation of the Iranianspeaking population. Some words of the Iranian-speaking group can be found in the Bukhara dialect. The occurrence of such terms as "vartishk" - quail, "stone" - "ketmon" indicates that the terms in the Iranian language have survived among the urban population. The city's Turkic-speaking population also spoke Persian. He lost his tongue. The word "Bukhara" is also a Hephthalite word (Livshits,1954). Authors of the ancient language of the Bukhara people say that it belongs to the dialect of the Sogdian language. (Barthold, 1926. p.29).

The language of the Bukhara people was analyzed by linguists in two ways. According to Narshakhi, F. Rosenberg and Henning confirmed that the language originated from the grammatical norms of the Sogdian language. According to Muhammad Narshahi, the people of Bukhara had preserved their ancient pre-Tajik language until the beginning of the 8th century. Only in the $X$ century this language was replaced by the Tajik language. But there are also people of different nationalities who have immigrated with the Tajiks. They did not mix with the townspeople, but kept their national traditions as they continued their relations with their relatives. They did not mix with the townspeople either because they lived together in the same area. The people of Mullo-Hoki-Roh mahalla are a good example of this. Another name for this neighborhood is Ponobixo. The name means that they came from the village of Ponob. When these people moved in, they bought many houses in the neighborhood and evicted the residents, giving the neighborhood a new name. The Ponobians are engaged to their relatives as well as their villages. The land and houses of the settlers in the village have been preserved, and in the hot summer days they have lived for some time in their courtyards in the village. This indicates that the city of Bukhara also played an important role in the country's internal migration. Among the Tajik population of Bukhara are those who migrated from the mountainous regions of Tajikistan, commonly known as "Kolobikho" Kolobliks. Although they mingled with the Tajiks of Bukhara, they kept their traditions. (Sukhareva,1958, p. 79).

Many tourists who came to Bukhara in the first half of the 19th century interacted with locals and called them Uzbeks. A. Borns admits that he is proud to be Uzbek, no matter what Bukhara you ask. During this period, most Bukhara residents considered Iranians to be Tajiks, not themselves. (Sukhareva, 1958)

A study of the population of Bukhara revealed that a Tajik-speaking man also spoke Uzbek. However, Uzbek families have preserved the traditions of their ancestors. Uzbeks such as Mangit, Nayman, Uch-Urug, Qirq-Juz, and Turkmen lived here. Most of them came from Khorezm. Such groups lived in Urgenj mahalla, west of Sheikh Jalal Gate, in Charmgaron 
mahalla, south of Shergiron Gate, and in OlimKhoja mahalla, south of Samarkand Gate. In the early 19th century, they lived with the nobility of the Khiva khanate in the Boyrobofon district of the craftsmen's mahalla, who had fled to Bukhara. These groups had no contact with each other as they had moved to Bukhara at different times. These segments of the population are able to speak Tajik fluently without forgetting their language. But the families of the aristocracy (sipo) among them remained faithful to their traditions and language. The nobles and servicemen of the Bukhara Khanate were of Uzbek descent and had their own tribes. The Uzbek language was predominant at the same level (Vyatkin, 1928). In Bukhara there were also groups that preserved their language. One of them was a Kenagas and a Kalmyk army living south of the Talipoch Gate. In addition to them, Tajik-speaking craftsmen lived in this part of the city. The second group of the Turkic-speaking population lived in the only area south of the aforementioned Samarkand Gate. They used to weave mats. A third group of Turkic-speaking populations made up half of the Kara-Kemal district on the east side of the city, north of the Mazar Gate. Half of the area was Tajik-speaking. Most of the locals were engaged in butchery or shoemaking. The Uzbek men living here have been given the name "bek". A small group of Turkic-speaking people belonged to the Bahrin tribe, who lived in the Morkush and Kyrgyzoyim mahallas, inhabited by the Mangit and Forty Hundred tribes, and they belonged to 10 wealthy families of this tribe. They reportedly lived in the Chashmai-Ayub area (Sukhareva, 1958). Subsequent reports suggest that these tribes migrated to Bukhara during the Russian occupation of Oratepa. The
Mangits and the Forties were made up of soldiers. During this period, the bourgeoisie was less formed in the Bukhara Khanate than in the Governor-General of Turkestan. But they could not reflect the interests and needs of the nation. Among the Tajiks of Bukhara and Samarkand at that time, the term "Uzbek" was not only an ethnic name, but also a social one, meaning "outskirts" or "villages." For the towns' people, religion was more important than nationality. Most of the towns' people were considered "Sunni Muslims." Uzbeks, Tajiks, and Iranians were united in a single social stratum to govern the country.

\section{RESULTS AND DISCUSSIONS}

In Bukhara, Iranians were also in the majority. They were isolated from the local population because they belonged to the Shia sect of Islam. During the reign of Amir Shah Murad, the descendants of the Kyzylbashli who remained in Samarkand and Bukhara differed from the local Turkic-speaking Uzbeks and Tajiks in their anthropology and language. Most Iranians lived in the Joyboriy mahalla in the southwestern part of the city, in the Chakar, Chukur mahalla, Vaqf mahalla, and Takhti-Chorbog guzar. In addition, the eastern border of the area where they live corresponds to the Walida-khan-Shahid district of the Alley branch. would include $z$. The second smaller group lived in the Topkhana district on the northwest side of Shahristan and made up about $60 \%$ of the population. The third group consisted of 28 relatives and lived in the Dost-Chorogos village on the west side of the Bukhara arch. Legend has it that five of their descendants lived here and were descendants of Ibrahim the silkspinner, who migrated from Iran to Bukhara in 
the late 18th century. The Sunnis of Bukhara lived separately from the Iranians. However, Iranian Shiites living near the Bukhara arch have assimilated with the local Ahoi because of their conversion to Sunni Islam. Although they mixed with the locals, they retained the ancient silk-spinning technology of their ancestors.

The Iranians also lived in the suburban villages of Qum-rabot, Totor-mahalla, and Joyboriberun. The people of these villages also practiced weaving because they were very close to the townspeople. The origins of Iranian groups are not the same. One is the descendants of those who migrated with the people of Merv during the reign of Amir Shah Murad in the late 18th century; The others were descendants of slaves brought to Bukhara from all of Khorasan and northern Afghanistan and later released with the consent of the Russian government. The third group had migrated from Iran to Bukhara voluntarily at various times. Most Iranians admit that their descendants migrated in the late 18th century. These migration processes continued until the Russian Revolution. The last settlers were called "Mashhadi" by the locals. Most of them are women. Wealthy Iranian merchants from Bukhara often followed in the footsteps of their wives. One of the ancient Iranian groups in Bukhara was the Artillerymen. While the group lived in the center of Shahristan, other groups lived in the Joybori neighborhood of the new part of the city. It was observed that this group of Iranians mixed with the local population and did not have any contact with their Iranian relatives. They did not have close contact with the residents of Joybori mahalla. The Iranians in the city are of Iranian descent, and seven generations have lived there so far. They came to Bukhara in search of work and settled there (Sukhareva,1958).

All Iranians living in Bukhara, with the exception of Dost-Chorogoshi, were united in the idea of a single Shiite religion, in close contact with each other, and separated from the local population. However, they later converted to Sunni Islam and assimilated with the local population. Despite the differences between the two sects of Islam, the Iranians had close ties with the local population of Bukhara. This is not only in the neighborhood between Uzbeks, Tajiks and Iranians living in the same neighborhood, but also in their marriage. However, near the Samarkand Gate in Bukhara, Shiites are also said to have attended Sunni ceremonies marking the day of Imam Hussein's death. It was a religious tolerance. But these ceremonies did not last long. (Yakubovsky, 1953. p.13-14) The Arabs were Tajik-speaking people living in two parts of Bukhara in the Arab district. The second was near the Sallah Gate on the southern outskirts of the city. (Barthold ,1963) The origin and migration of both groups are not known. However, before the Arab invasion of Central Asia, the Quraysh and other Arab tribes settled in the deserts of Bukhara and Karshi. The Arabs of Bukhara were also engaged in cattle breeding in the oasis. They were engaged in the sale of Karakol leather, which led to the formation of the Karakol leather market in the Sallakhona district of the city. The Arabs settled in the central part of the city, so they moved to the city in ancient times. They moved from the time of the Arab conquest of Bukhara or with the advent of Islam. The Arab settlement is located outside the ancient city of Kutayba, where they settled. Muhammad Narshahi or his translator, Abu Nasr Ahmad al-Qubbawi, recalled that the 
place where the Arabs stood was in front of the "fortress gate." (Narshakhi, 1991.) But because he was young, his mother ruled the country. Every time the Arabs conquered Bukhara, he called them to Islam. But the people of Bukhara always worshiped their religion. For the fourth time, Kutayba invaded and inflicted various persecutions on the people in order to propagate Islam, and placed Arabs in every household to teach them Islam. Kutayba built mosques and destroyed the works of firefighters (Narshakhiy, 1991). Sukhareva localized the Arabs in front of the newly built arch gate. (Sukhareva, 1958, p. 84). Economic and cultural ties between the peoples of Bukhara and Afghanistan also developed in the late Middle Ages or during the Bukhara Khanate and the Bukhara Emirate. Of course, trade caravan routes play an important role in the development of these relations. The shortest routes of these roads are Bukhara Chorjoy (Chahorjoy) - Caliph - Balkh - Kabul, Bukhara Balkh - Kabul, and through Bukhara Karshi Guzar, first to Boysun and Sherabad oasis. It was connected to the Sherabad-Kohitang-Kelif route and to major trade and handicraft centers such as Sherabad-Termez-Ayvaj-Kabul, Mazar-i-Sharif and Balkh. In the late 19th and early 20th centuries, Afghan traders and artisans lived in several principalities of the Bukhara Emirate. If tea, pistachios, almonds, leather, wool products were imported from Afghanistan to Bukhara, sugar, sugar, iron, cast iron, iron pots, copper, matches, chests, furs from Russia were imported to Bukhara via Afghanistan. Between 1900 and 1913, the range of products exported to Afghanistan increased, including leather, paper, charcoal, iron and copper wire, kerosene, lamps, candles, soap, and candlesticks. (Hayitov,
2020. pp. 27-30). Therefore, traders of the Bukhara Emirate also lived in the cities of Herat, Balkh, Mazar-i-Sharif, Tashkurgan, Oybalik, Andkhoy, Maymana, Afghanistan.

\section{CONCLUSION}

In conclusion, we can say that the principalities of the Bukhara Emirate were inhabited by Turks and Afghans in towns and villages in the early twentieth century. Bukhara was home to 7,000 Turks and 4,000 Afghans. According to sources, the Afghans lived in Bukhara, Karshi, Charjou, Karki, Termez, Denau, Sherabad and engaged in various trades. It can be observed that they did not live in one place. According to historical sources, people came to Karki from 1914 to 1915 from Kandahar, Tashkurgan, Oybalik, Shiberghan, Kabul, Balkh, Sabgan, Andhoy, Maymana, Herat, Akcha and Afghanistan.

\section{REFERENCES}

1. Sayyid Amir Alimkhan. History of grief of the people of Bukhara. T., "Science", $1991.2 \mathrm{p}$.

2. Masson M.E. "To the historical topography of Herat XV century., Sat. “The Great Uzbek Poet”, Tashkent, 1948. p. 139-140.

3. Yakubovskiy A.Yu. Ibn Sina, Sat. "Ibn Sina", Tashkent, 1953. p. 13-14

4. Sukhareva O.A. On the history of the cities of the Buksar Khanate. Publishing house of the Academy of Sciences of UzSSR, T., 1958, p. 78)

5. Kholikov Z.E. Termez and Chaganiyan in the Late Middle Ages based on written and material sources. Diss. At the sois.cand.st. sciences. 2001 
6. Yusupovich, K. S. (2020). The Emergence Of Religious Views Is Exemplified By The Southern Regions. The American Journal of Social Science and Education Innovations, 2(10), 143-145.

7. 7.Isarov U. I. Reviews of Bactrian irrigation system in the bronze age //Ўтмишга назар журнали. - 2019.

8. Isarov U. I. Reviews About Early Nomads In Central Asia //The American Journal of Interdisciplinary Innovations and Research. - 2020. 